\title{
Taphonomy of the fossil insects of the middle Eocene Kishenehn Formation
}

Dale E. Greenwalt, Tim R. Rose, Sandra M. Siljestrom, Yulia S. Goreva, Kurt N. Constenius, and Jonathan G. Wingerath

Acta Palaeontologica Polonica 60 (4), 2015: 931-947 doi:http://dx.doi.org/10.4202/app.00071.2014

The lacustrine oil shales of the Coal Creek Member of the Kishenehn Formation in northwestern Montana comprise a relatively unstudied middle Eocene fossil insect locality. Herein, we detail the stratigraphic position of the fossiliferous unit, describe the insect fauna of the Coal Creek locality and document its bias towards very small but remarkably pre-served insects. In addition, the depositional environment is examined and the mineral constituents of the laminations that comprise the varves of the Kishenehn oil shale are defined. Fifteen orders of insects have been recorded with the majority of all insects identified as aquatic with the families Chironomidae (Diptera) and Corixidae (Hemiptera) dominant. The presence of small aquatic insects, many of which are immature, the intact nature of $>90 \%$ of the fossil insects and the presence of Daphnia ephippia, all indicate that the depositional environment was the shallow margin of a large freshwater lake. The fossil insects occur within fossilized microbial mat layers that comprise the bedding planes of the oil shale. Unlike the fossiliferous shales of the Florissant and Okanagan Highlands, the mats are not a product of diatomaceous algae nor are diatom frustules a component of the sediments or the varve structure. Instead, the varves are composed of very fine eolian siliciclastic silt grains overlaid with non-diatomaceous, possibly cyanobacteria-derived microbial mats which contain distinct traces of polyaromatic hydrocarbons. A distinct third layer composed of essentially pure calcite is present in the shale of some exposures and is presumably derived from the seasonal warming-induced precipitation of carbonate from the lake's waters. The Coal Creek locality presents a unique opportunity to study both very small middle Eocene insects not often preserved as compression fossils in most Konservat-Lagerstätte and the processes that led to their preservation.

Key words: Diptera, Hemiptera, taphonomy, varve, depositional environment, Eocene, USA, Montana.

Dale E. Greenwalt [reenwaltD@si.edu] and Jonathan G. Wingerath [wingerat@ si.edu], Department of Paleobiology, NMNH, Smithsonian Institution, P.O. Box 37012 MRC 121, Washington, D.C. 20013-7012, USA; Tim R. Rose [roset@ si.edu] and Yulia S. Goreva [gorevay@si.edu], Department of Mineral Sciences, NMNH, Smithsonian Institution, P.O. Box 37012 MRC 119, Washington, D.C. 20013-7012, USA; Sandra 
M. Siljestrom [SiljestromS@ si.edu], Department of Chemistry, Materials and

Surfaces, SP Technical Research Institute of Sweden, Box 857, 50111 Borås,

Sweden, and Department of Mineral Sciences, NMNH, Smithsonian

Institution, P.O. Box 37012 MRC 119, Washington, D.C. 20013-7012, USA;

Kurt N. Constenius [kconstenius@comcast.net], Section of Vertebrate Fossils, Carnegie Museum of Natural History, Tucson, AZ 85704, USA.

This is an open-access article distributed under the terms of the Creative Commons Attribution License (for details please see creativecommons.org), which permits unrestricted use, distribution, and reproduction in any medium, provided the original author and source are credited.

For Full text $(1,348.3 \mathrm{kB})$ 